\title{
The Influence of Burning Temperature of MIRHA On Mechanical Properties of Foamed Concrete
}

\author{
Ridho Bayuaji ${ }^{1}$
}

\begin{abstract}
Microwave incinerator as one of the modern incinerators is proposed to produce amorphous Microwave incinerated Rice Husk Ash (MIRHA) with high pozzolanic reactivity thus can significantly enhance concrete properties. Analyses on the MIRHA with various burning temperature, the temperatures used were $300^{\circ} \mathrm{C}, 400^{\circ} \mathrm{C}, 500^{\circ} \mathrm{C}, 600^{\circ} \mathrm{C}$ and $800^{\circ} \mathrm{C}$. To determine the physical and chemical properties of MIRHA with various burning temperature were also conducted through $X$-ray diffraction (XRD), X-ray Fluorescence (XRF), scanning electron microscope (SEM) and mechanical properties test. The results showed that the MIRHA at $3000 \mathrm{C}$ could be used as a cementitious material with optimum OPC replacement at $20 \%$. It was found that MIRHA foamed concrete at $3000 \mathrm{C}$ achieved more than $100 \%$ higher strength compared to foamed concrete without MIRHA.
\end{abstract}

Keywords-foamed concrete, microwave incinerated rice husk ash (MIRHA), burning temperature.

\section{INTRODUCTION}

$\mathrm{C}$ oncrete is a construction material composed of Ordinary Portland Cement (OPC), aggregate, water, and chemical admixtures as well as other cementitious materials such as fly ash and slag cement [1]. OPC is expensive in the current market and not friendly to nature. By producing one ton of cement is associated with similar amount of Carbon dioxide $(\mathrm{CO} 2)$ will be discharged into the atmosphere, currently more than 2.5 billion ton of cement is produced all over the world [2, $3]$. Cement replacement material (CRM) is one of the solutions for this problem. The utilization of the agricultural residue such as rice husk ash, as cement replacement is a new trend in concrete technology in this century $[4,5]$. Besides, as far as the sustainability is concerned, it will also help to solve problems otherwise encountered in disposing of the wastes $[6,7]$. Together with renewable energy technologies, it offers the promise of a sustainable energy future as world seeks to improve the quality of life for present citizens and future generations alike.

Rice husk ash is one of the CRM that can be used in building technology. More than $90 \%$ of world rice production comes from South and South East Asia [8]. This is due to rice is the most important food in Asia. When producing rice, rice husk will be thrown away as waste material. This can cause pollution when talk about disposing the waste. Rice husk is also recognized as a potential source of energy. Moreover, $20 \%$ of the ash contain $95 \%$ of amorphous silica that make the rice husk ash can be utilized economically [8]. This rice husk is burning under controlled conditions to make sure the quality of the ash is good to utilize the resultant ash as building material [9].

According to Mehta [10] in 1978, he investigated how the preprocessing effect on the pozzolanic reactivity of RHA. In 2002, Nehdi et. al [11] investigated the effect of RHA in performance of concrete. In their research, the effect of different burning temperature of RHA also included same like the first objective of the author in this

${ }^{1}$ Ridho Bayuaji is with Department of Civil Engineering, Faculty of Civil Engineering and Planning, Institut Teknologi Sepuluh Nopember, Surabaya, 60111, Indonesia. E-mail: bayuaji@ce.its.ac.id. research. The different is how the material burned. In 2008, Memon, Shaikh and Akhbar [9] explore effect of RHA in production of low cost self-compacting concrete in Pakistan construction industry.

The other hand, by using lightweight concrete, the self-weight of the concrete will be reduced. This will bring a lot of advantages for example cost reduction. When combining RHA as CRM and foamed concrete (lightweight concrete), it can be economically and environmentally friendly. This research focused on the burning procedure to obtain RHA that is highly reactive so it can be used as cement replacement material to improve building technology. Not only that, this is also due to environmental concern. By using RHA, the production of cement can be reduced as well as $\mathrm{CO} 2$ in air. In addition, if there is no proper burning process of RHA, this can reduce quality and quantity of a product. Plus, this also can make environment polluted. So, high temperature microwave incinerator in Universiti Teknologi PETRONAS (UTP) has been used which produce best quality of rice husk ash which called MIRHA (Microwave incinerated Rice Husk Ash). No research had been done due to burning temperature profile of this equipment. So the author used this opportunity to do this research. After the determined the burning temperature profile, the optimum temperature of RHA can be observed. As a consequent, best quality of MIRHA will be produced.

\section{METHOD}

Rice milling plant Bernas, Malaysia is the source of rice husk that the author used in this research [12]. To reduce moisture content of Rice Husk Ash (RHA), Bernas had dried the rice husk under direct sunlight [12]. This can reduce the amount of smoke produced when burning the rice husk. In addition, it also can reduce air pollution.

In this research, the author used new equipment from Universiti Teknologi Petronas (UTP), high temperature microwave incinerator. The raw rice husk ash is shown in Figure 1 and Figure. 2 shows the microwave incinerated equipment used in this research. To achieve the objective of this research, the author varies the temperature of rice husk burning to get the optimum 
strength of pozzolanic activity. Temperature used are $300{ }^{\circ} \mathrm{C}, 400{ }^{\circ} \mathrm{C}, 500{ }^{\circ} \mathrm{C}, 600{ }^{\circ} \mathrm{C}$ and $800{ }^{\circ} \mathrm{C}$. Figure 3 shows the rice husk ash after burning into microwave incinerator called MIRHA (Microwave Incinerated Rice Husk Ash).

To form higher strength of concrete, RHA must be finer than the cement. So that RHA can easily fill between the free spaces of cement. So, the RHA need to grind in a equipment called Los Angeles (LA) Abrasion machine. Figure 4 shows the MIRHA after grinding.

The constituent materials used in the laboratory to produce foamed concrete comprised (i) Portland cement (Ordinary Portland Cement BSEN 197-1-2000) (ii) natural sand, with $100 \%$ passing $425 \mathrm{~mm}$ sieved (BS EN 12620:2002), (iii) MIRHA, with high reactive silica content, controlled combustion of ash (BS EN 450:2000) and (iv) free water (BS 3148:1980) (v) superplasticizer (BS EN 934-2:2001). The surfactant used for the production of the preformed foam by aerating palm oil based (typical of industry practice) a ratio of 1:30 (by volume), aerated to a density of $110 \mathrm{~kg} / \mathrm{m} 3$ (ASTM C 869-91 (reapproved 1999), ASTM C 796-97). The chemical properties of MIRHA and OPC used are shown in Table 3

In this research, the author had done 2 phases of mixing. The first phase is to determine the optimum temperature of MIRHA as shown in Table 1. The second phase will be conducted by using the optimum temperature of MIRHA to determine mechanical properties of foamed concrete as shown in Table 2. The Specimen used was a cube with a dimension of $50 \mathrm{~mm}$ and 7 cubes per mix. The author had done the curing based on BS EN 12390-2:2000. After 24 hours casting, the specimens the author placed them for curing at $20 \pm$ $2{ }^{\circ} \mathrm{C}$.

\section{RESULT AND DISCUSSION}

The pattern of temperature burning was shown in Figure 5. These graph shown varies the temperature burning which were $300{ }^{\circ} \mathrm{C}, 400{ }^{\circ} \mathrm{C}, 500{ }^{\circ} \mathrm{C}, 600{ }^{\circ} \mathrm{C}$ and $800{ }^{\circ} \mathrm{C}$. Based on Figure 5 , basically the pattern of all graph are almost the same. From the graph, when approximately after 200 minutes of burning, the temperature will increase rapidly and after reach the temperature required, the microwave source will stop but it will continuously burning because heat in the incinerator will not stop.

This situation make the temperature continuously increase and after 20 to 30 minutes, the temperature will decrease in about 10 to 20 minutes. Maybe because there is some balance moisture from the rice husks. Then, the temperature will increase back approximately in 1 hour because maybe there are balance heats in the incinerator before it decreases until reach the normal temperature. Because of the graph of temperature burning is almost the same, it shows that the incinerator is stable and in a good condition. Based on Figure 6, MIRHA at $300{ }^{\circ} \mathrm{C}$, $400{ }^{\circ} \mathrm{C}, 500{ }^{\circ} \mathrm{C}$, and $800{ }^{\circ} \mathrm{C}$ the highest peak of the graph which is at $22^{\circ} 2 \theta$ shows the presence of crystalline. And the gradual dense scatter of the graph shows the amorphous state. So MIRHA at $300{ }^{\circ} \mathrm{C}$, $400{ }^{\circ} \mathrm{C}, 500{ }^{\circ} \mathrm{C}$, and $800{ }^{\circ} \mathrm{C}$ of burning is in partially crystalline state. For $600{ }^{\circ} \mathrm{C}$ burning of MIRHA don't have the highest peak, so the sample is in amorphous state. So, $600{ }^{\circ} \mathrm{C}$ is not the optimum temperature burning of MIRHA. To get a good quality and high strength of MIRHA, the pattern of MIRHA must be in partially crystalline [13].IX-Ray Fluorescence (XRF) test conducted to identify the chemical composition compound of MIRHA. Powder sample of $300{ }^{\circ} \mathrm{C}$, $400{ }^{\circ} \mathrm{C}, 500{ }^{\circ} \mathrm{C}, 600{ }^{\circ} \mathrm{C}$ and $800{ }^{\circ} \mathrm{C}$ temperature burning of MIRHA tested. Table 3 shows the material contents inside MIRHA with different burning temperature. Based on Table 3, $\mathrm{SiO} 2$ is the main component in of the chemical component in RHA. This result is meet with the previous researcher had done [13] which is the silica content in RHA is between $80-95 \%$. According to Kusbiantoro [12], the present of $\mathrm{SiO} 2$ and $\mathrm{K} 2 \mathrm{O}$ will decrease the heat evolution in concrete hydration process. As a consequence, the concrete properties also will improve.

Figure 7 shows microstructure of raw rice husk before burning. In Figure 8, shows the microstructure for different burning temperature of MIRHA. Comparing the microstructure of raw rice husk and rice husk ash after burning and grinding, the structure of MIRHA is finer than the raw rice husk to make sure which one either $300{ }^{\circ} \mathrm{C}, 400{ }^{\circ} \mathrm{C}, 500{ }^{\circ} \mathrm{C}, 600^{\circ} \mathrm{C}$ and $800^{\circ} \mathrm{C}$ of burning is the optimum temperature burning of MIRHA, the author decided to compare the compressive strength of mortar when MIRHA for each temperature burning combine with cement. There are 6 batches of mixing including mortar without MIRHA and 7 samples for each batch. The age of each mortar is 28 days. Figure 9 shows the graph of the average compression strength in mortar against temperature of MIRHA in the mortar. Based on this graph, it shows that burning temperature of MIRHA at $300{ }^{\circ} \mathrm{C}$ is slightly higher than the others. So, the author concludes that the optimum temperature burning of MIRHA is at $300{ }^{\circ} \mathrm{C}$. Lower burning temperature of UTP Microwave Incinerator shows that by using this machine, the user can reduce cost and time burning the RHA. The strength development of foamed concrete containing various percentages of MIRHA at $300 \mathrm{oC}$ was monitored at ages 3,7 , and 28 days. Figure 10 shows the compressive strength result with various mix proportion plotted against time.

\section{CONCLUSION}

In conclusion, it can be confirmed that MIRHA at $300^{\circ} \mathrm{C}$ can be utilized as a cement replacement material with $20 \%$ replacement as the optimum value. MIRHA at $300^{\circ} \mathrm{C}$ can improve the compressive strengths of foamed concrete.

\section{REFERENCES}

[1] P. K. Mehta, "Mineral Admixture for Concrete - An Overview of Recent Developments.." in Advance in Cement and Concrete. In : Proceedings of an Engineering Foundation Conference, ASCE, Ed. University of Newhampshire, Durham ASCE, 1994, pp. 243 $-256$.

[2] P. K. Mehta, . "Role of Pozzolanic and Cementitious Material in Sustainable Development of the Concrete Industry. Fly Ash, Silica Fume, Slag, and Natural Pozzolans in Concrete," in Proceedings of the 6 CANMET/ACI/JCI International Conference, Bangkok, 1998, pp. 1-20.

[3] A. M. Neville, Properties of Concrete (4th edn). Longman, London, 2006.

[4] D. D. Bui, "Rice husk ash as a mineral admixture for high performance concrete." vol. PhD: Delft University 2001 
[5] D. D. Bui, J. Hu, and P. Stroeven, "Particle Size Effect on the Strength of Rice Husk Ash Blended Gap-Granded Portland Cement Concrete," Cem Concr Res 27 pp. 357-366, 2005.

[6] MF Nuruddin, A Kusbiantoro, and N. Shafiq, "Microwave incinerated rice husk ash (MIRHA) and it's effects on concrete strength," in International IMS Conference On Applications Of Traditional And High Performance Materials In Harsh Environments, American University of Sharjah, 2008, pp. 23-24.

[7] MF Nuruddin, Sobia Anwar Qazi, Andri Kusbiantoro, and N. Shafiq, "Utilisation of waste material in geopolymeric concrete," Proceedings of the ICE-Construction Materials, vol. 164, pp. 315327, 2011.

[8] S. Balakrishnan, "Rice Husk Ash Silica as Support Material for Iron and Ruthenium Based Heterogeneous Catalyst." vol. Master Malaysia: Universiti Sains Malaysia, 2006.

[9] R. Bayuaji, "Effects Of Microwave Incinerated Rice Husk Ash (Mirha) On Hydration And Mechanical Properties Of Foamed
Concrete," in Civil Engineering. vol. Ph.D. Bandar Sri Iskandar, Malaysia: Universiti Teknologi Petronas, 2010.

[10] P. K. Mehta, "Siliceous ashes and hydraulic cements prepared there from." vol. 4105459, U. Patent, Ed., 1978.

[11] J. D. M. Nehdi, A. El Damatty, "Performance of Rice Husk Ash Produced Using A New Technology as A Mineral Admixture In Concrete," Cement and Concrete Research, vol. 33 August 2003 , Pages 1203-1210, pp. 1203-1210, 2003.

[12] Kusbiantoro Andre and M. F. Nuruddin, "The Effect of Microwave Incinerated Rice Husk Ash (MIRHA) On Concrete Properties," 2007.

[13] C. C. Guilherme, Romildo D.T.F, and Eduardo de M.R.F, "Use of Ultrafine Rice Husk Ash with High-Carbon Content as Pozzolan in High Performance Concrete," Material and Structure pp. 983 992, 2008.

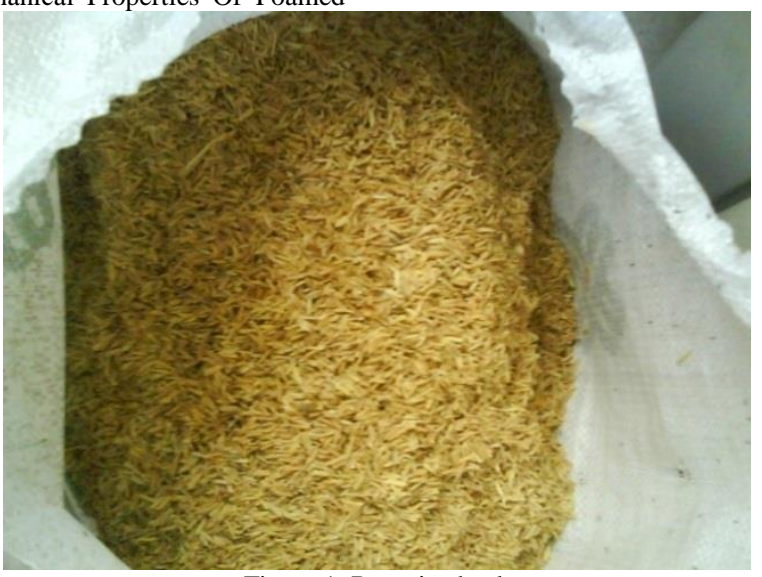

Figure 1. Raw rice husk

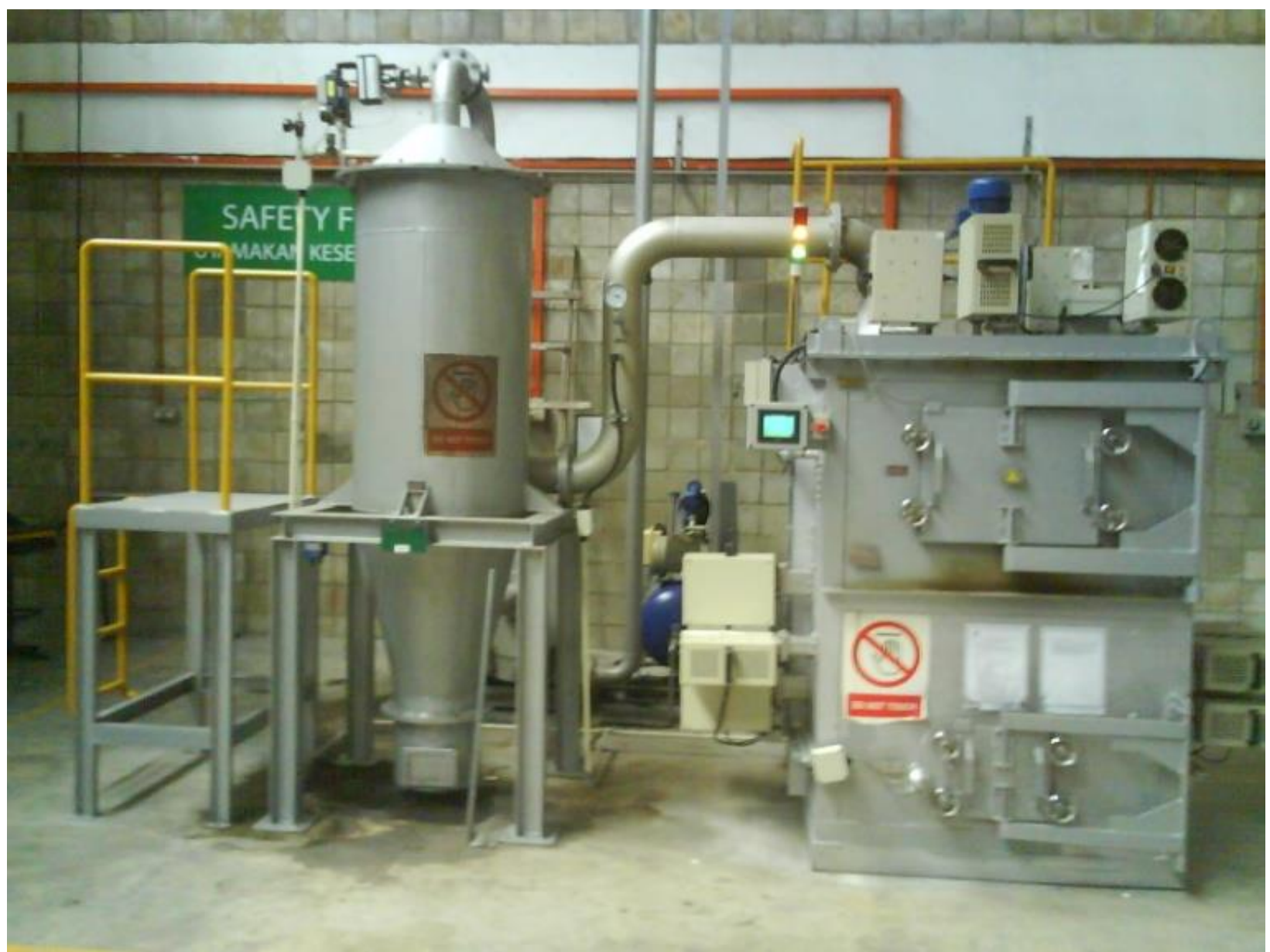

Figure 2. Automatic Microwave Incinerator 


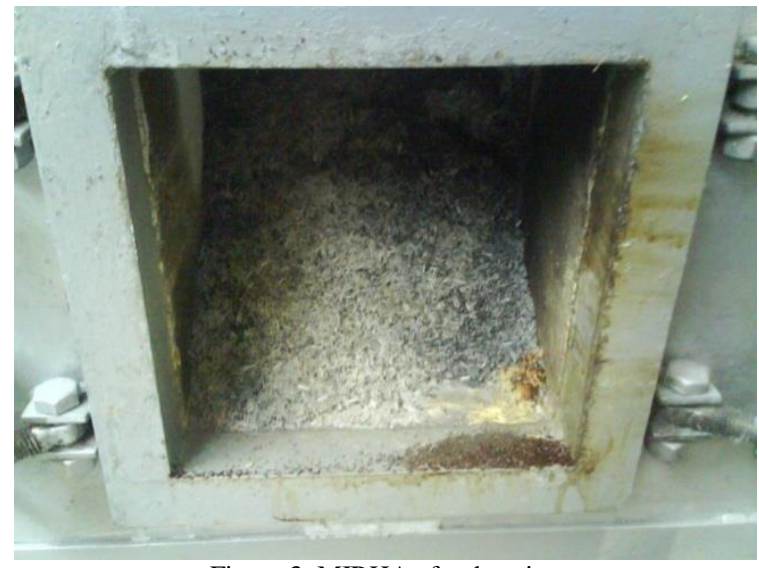

Figure 3. MIRHA after burning

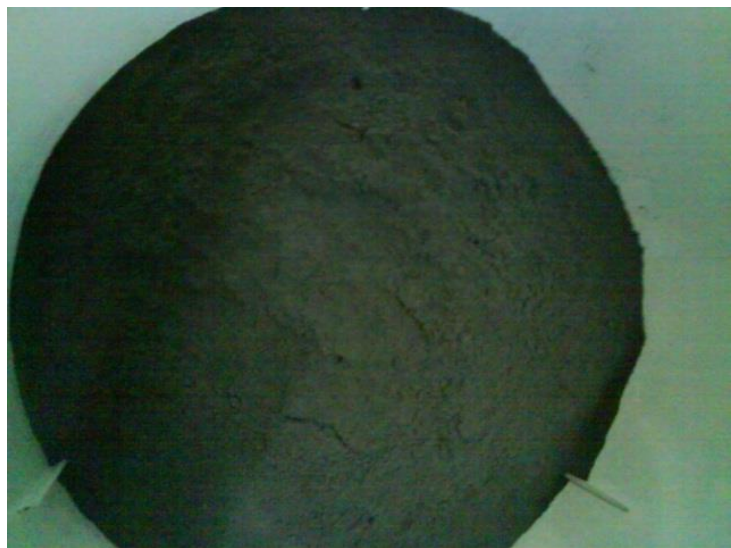

Figure 4. MIRHA after grinding

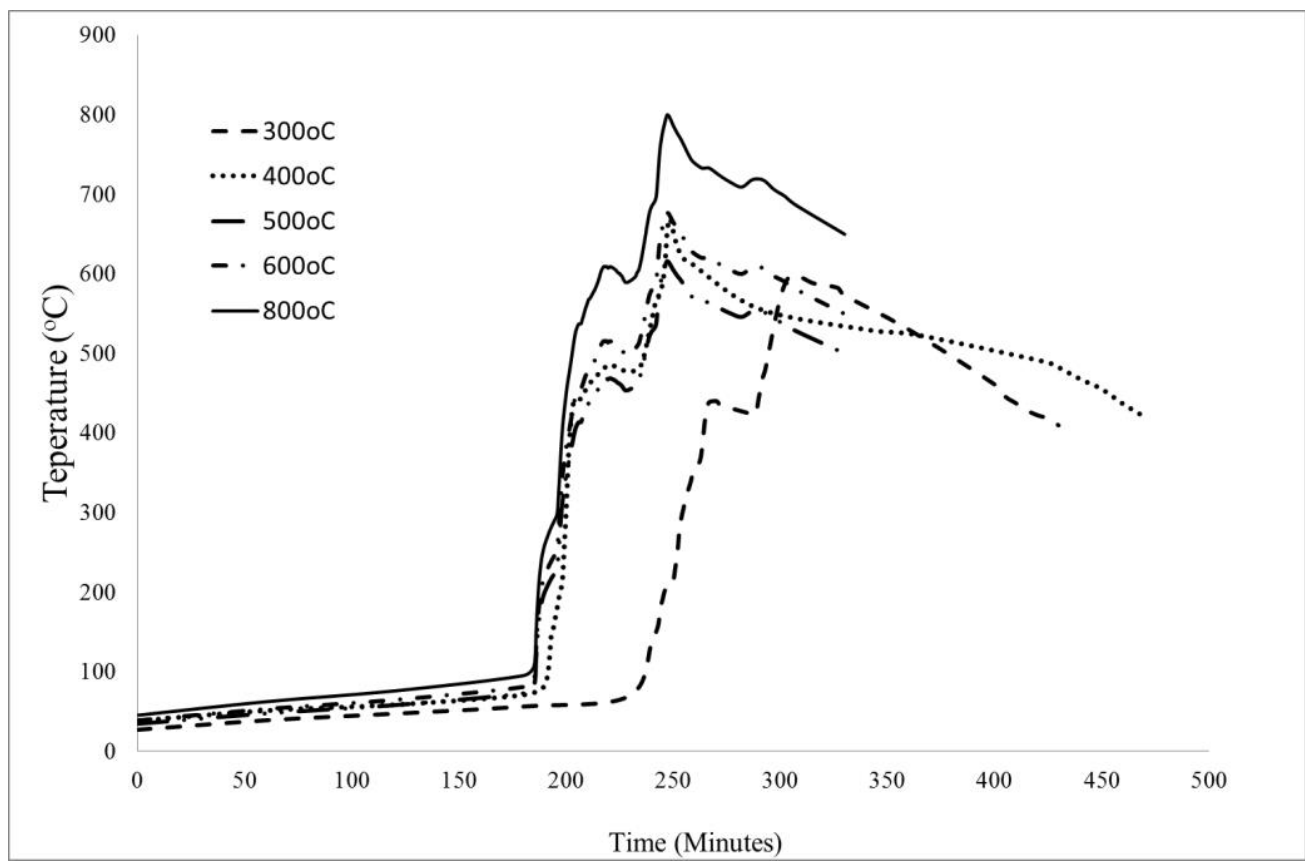

Figure 5. Comparison of different temperature burning of MIRHA

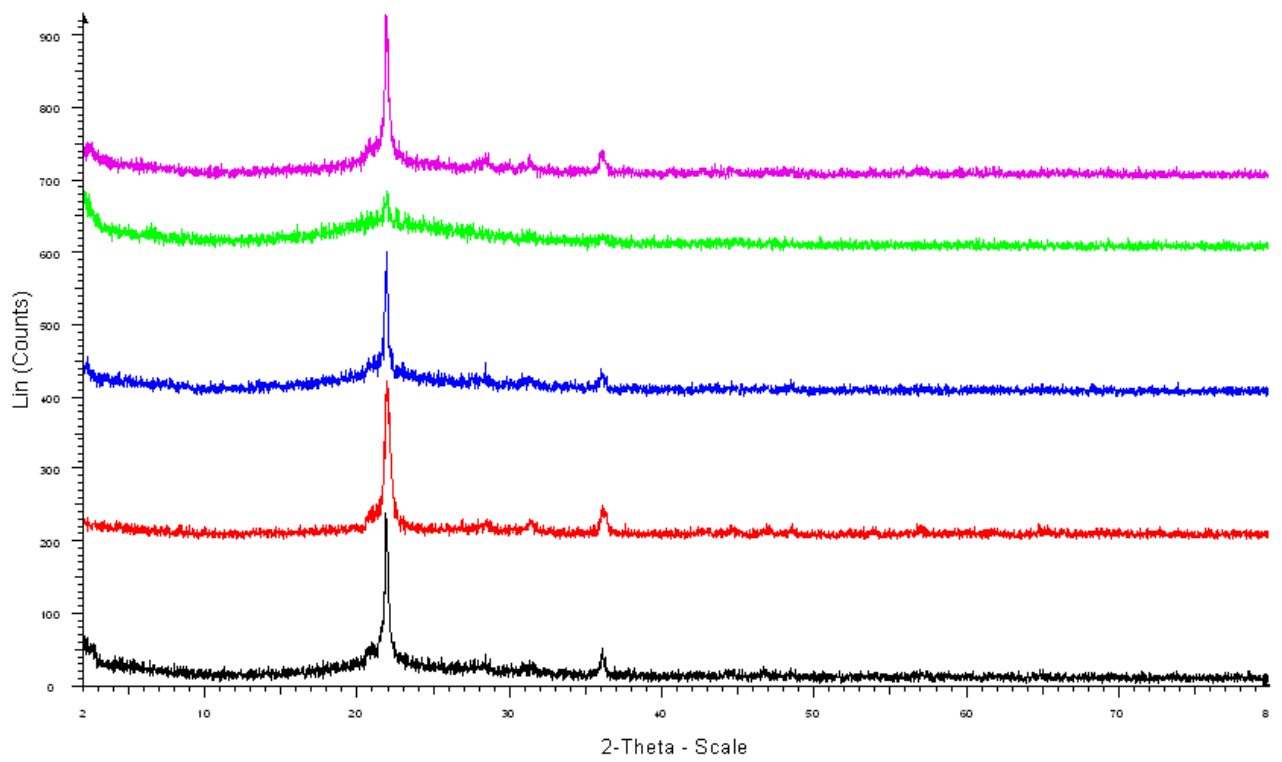

Figure 6. XRD result for each MIRHA temperature 


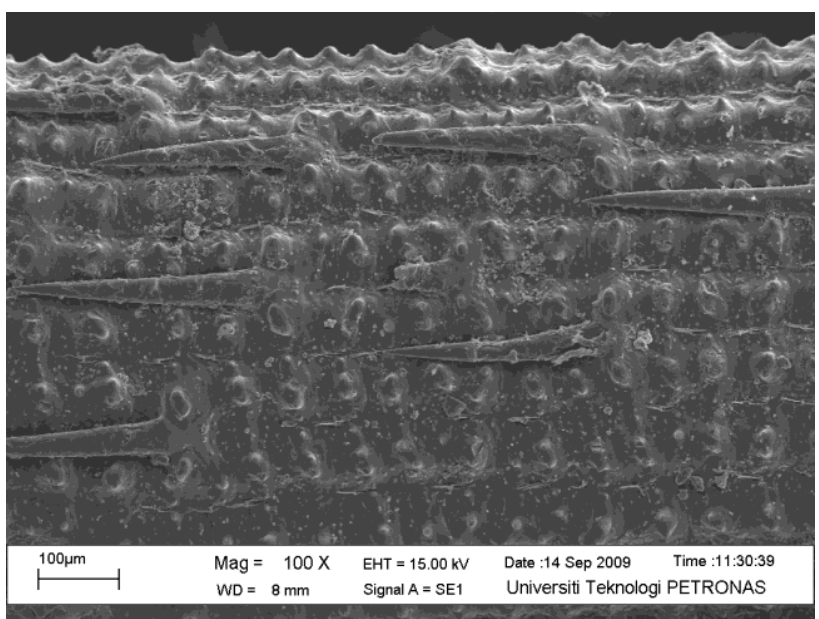

Figure 7. Microstructure for raw rice husk
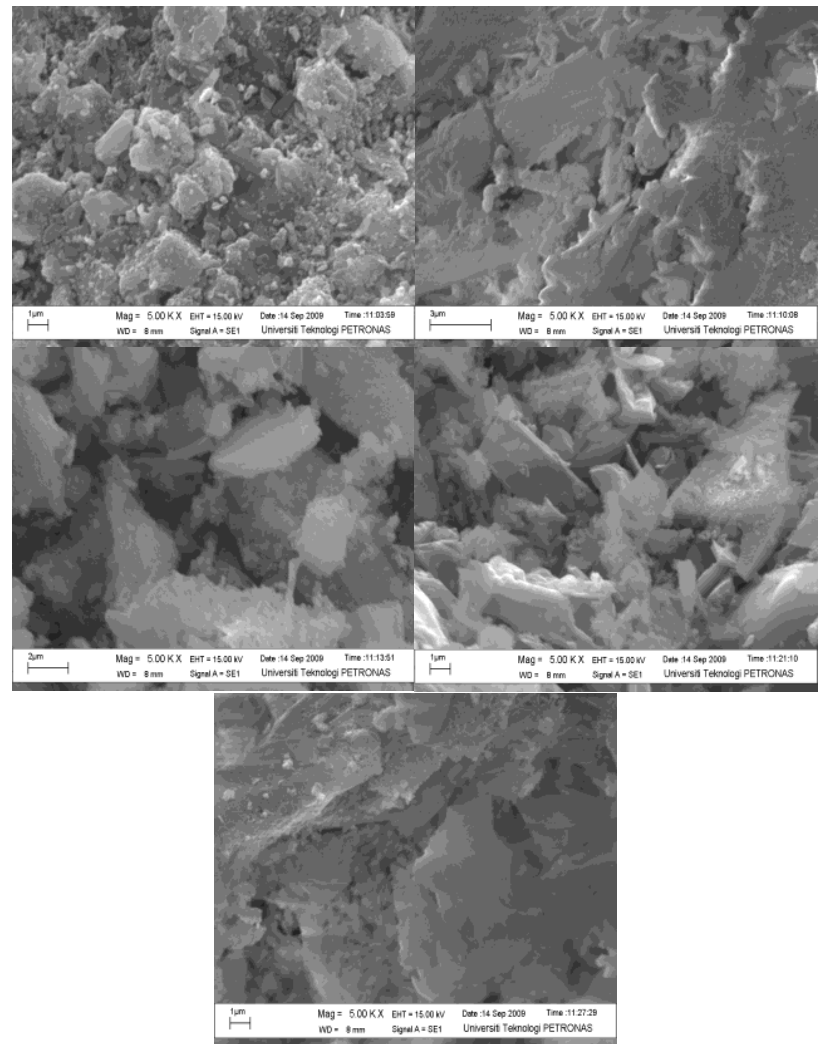

Figure 8. Microstructure for MIRHA at (a) $300{ }^{\circ} \mathrm{C}$ (b) $400{ }^{\circ} \mathrm{C}$ (c) $500{ }^{\circ} \mathrm{C}$ (d) $600{ }^{\circ} \mathrm{C}$ (e) $800{ }^{\circ} \mathrm{C}$

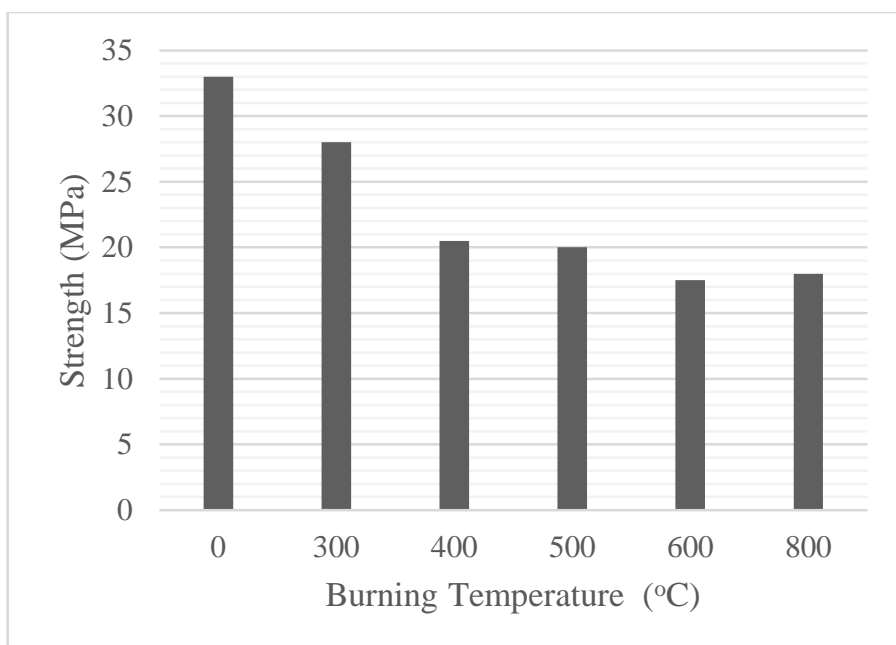

Figure 9. Graph of average compression strength against MIRHA with different temperature that partially put in mortar 


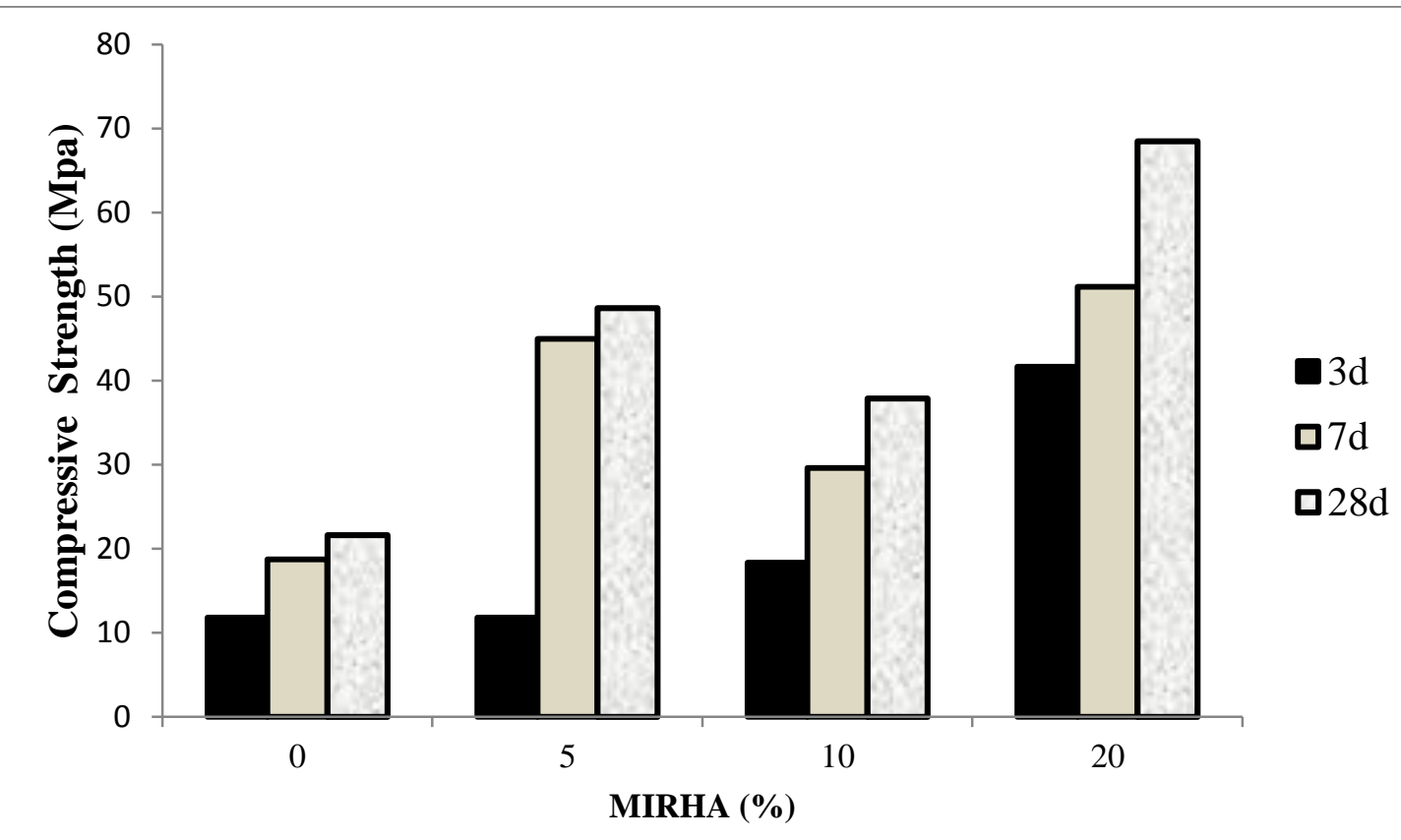

Figure 10. Compressive strength results for foamed concrete with different percentage of MIRHA

TABLE 1.

MIX PROPORTION OF MIRHA ON CEMEN PASTE

\begin{tabular}{lccccc}
\hline \hline MIRHA & $\begin{array}{c}\text { Cement } \\
(\mathrm{kg})\end{array}$ & $\begin{array}{c}\text { Water } \\
(\mathrm{kg})\end{array}$ & $\begin{array}{c}\text { Dry } \\
\text { fine } \\
\text { Aggre- } \\
\text { gate } \\
(\mathrm{kg})\end{array}$ & $\begin{array}{c}\text { MIRHA } \\
(\mathrm{kg})\end{array}$ & $\begin{array}{c}\mathrm{SP} \\
(\mathrm{kg})\end{array}$ \\
\hline No & 1.125 & 0.545 & 3.094 & 0.000 & 0.000 \\
$\mathrm{MIRHA}$ & & & & & \\
$300^{\circ} \mathrm{C}$ & 1.013 & 0.545 & 3.094 & 0.113 & 0.055 \\
$400^{\circ} \mathrm{C}$ & 1.013 & 0.545 & 3.094 & 0.113 & 0.055 \\
$500^{\circ} \mathrm{C}$ & 1.013 & 0.545 & 3.094 & 0.113 & 0.055 \\
$600^{\circ} \mathrm{C}$ & 1.013 & 0.545 & 3.094 & 0.113 & 0.055 \\
$800{ }^{\circ} \mathrm{C}$ & 1.013 & 0.545 & 3.094 & 0.113 & 0.055 \\
\hline \hline
\end{tabular}

TABLE 2 .

MIX PROPORTION FOAMED CONCRETE

\begin{tabular}{ccccc}
\hline \hline $\begin{array}{c}\text { MIRHA } \\
(\boldsymbol{\%})\end{array}$ & $\begin{array}{c}\text { Cement } \\
(\mathbf{k g})\end{array}$ & $\begin{array}{c}\text { Water } \\
(\mathbf{k g})\end{array}$ & $\begin{array}{c}\text { MIRHA } \\
(\mathbf{k g})\end{array}$ & $\begin{array}{c}\text { Foam } \\
(\text { liter })\end{array}$ \\
\hline 0 & 3.516 & 1.230 & 0.000 & 0.8 \\
5 & 3.340 & 1.230 & 0.176 & 0.8 \\
10 & 3.164 & 1.230 & 0.352 & 0.8 \\
20 & 2.813 & 1.230 & 0.703 & 0.8 \\
\hline \hline
\end{tabular}

TABLE 3.

CHEMICAL COMPOSITION OF MIRHA WITH DIFFERENT BURNING TEMPERATURE

\begin{tabular}{|c|c|c|c|c|c|}
\hline Oxides & $\begin{array}{c}\text { MIRHA (\%) } \\
\left(300^{\circ} \mathrm{C}\right)\end{array}$ & $\begin{array}{c}\text { MIRHA (\%) } \\
\left(400^{\circ} \mathrm{C}\right)\end{array}$ & $\begin{array}{c}\text { MIRHA (\%) } \\
\left(500^{\circ} \mathrm{C}\right)\end{array}$ & $\begin{array}{c}\text { MIRHA (\%) } \\
\left(600^{\circ} \mathrm{C}\right)\end{array}$ & $\begin{array}{c}\text { MIRHA (\%) } \\
\left(800^{\circ} \mathrm{C}\right)\end{array}$ \\
\hline $\mathrm{CaO}$ & 1.080 & 0.990 & 1.120 & 1.190 & 1.030 \\
\hline $\mathrm{SiO}_{2}$ & 87.150 & 88.580 & 87.417 & 85.610 & 87.380 \\
\hline $\mathrm{Al}_{2} \mathrm{O}_{3}$ & 0.190 & 0.110 & 0.100 & 0.000 & 0.110 \\
\hline $\mathrm{Fe}_{2} \mathrm{O}_{3}$ & 0.400 & 0.264 & 0.125 & 0.248 & 0.151 \\
\hline $\mathrm{Na}_{2} \mathrm{O}$ & 0.000 & 0.000 & 0.000 & 0.000 & 0.000 \\
\hline $\mathrm{K}_{2} \mathrm{O}$ & 5.460 & 5.032 & 5.394 & 6.038 & 5.438 \\
\hline $\mathrm{MgO}$ & 0.879 & 0.840 & 0.986 & 1.010 & 1.050 \\
\hline $\mathrm{SO}_{3}$ & 0.617 & 0.425 & 0.525 & 0.692 & 0.621 \\
\hline $\mathrm{CO}_{2}$ & 0.000 & 0.000 & 0.000 & 0.000 & 0.000 \\
\hline $\mathrm{MnO}$ & 0.104 & 0.100 & 0.099 & 0.114 & 0.102 \\
\hline $\mathrm{ZnO}$ & 0.037 & 0.022 & 0.023 & 0.049 & 0.026 \\
\hline $\mathrm{Rb}_{2} \mathrm{O}$ & 0.037 & 0.035 & 0.036 & 0.038 & 0.036 \\
\hline $\mathrm{Cl}$ & 0.376 & 0.112 & 0.365 & 0.782 & 0.209 \\
\hline $\mathrm{P}_{2} \mathrm{O}_{5}$ & 3.670 & 3.490 & 3.810 & 4.230 & 3.850 \\
\hline
\end{tabular}

